\title{
The persistence and function of living roots on lodgepole pine snags and stumps grafted to living trees
}

\author{
Erin C. FrASER, Victor J. LIEFFERS*, Simon M. LANDHÄUSSER \\ Centre for Enhanced Forest Management, department of Renewable Resources, university of Alberta, Edmonton, Alberta, Canada T6G 2E3
}

(Received 16 May 2006; accepted 27 June 2006)

\begin{abstract}
In Alberta, Canada, pairs of grafted lodgepole pine trees were selected to study the longevity and location of live roots of snags that were grafted to living trees, to determine the impact of these live residual roots on the diameter growth of the living tree. In a second study, dense groups of grafted trees were manually thinned and one leave tree was left to grow for two growing seasons. For both studies, roots were excavated. Results indicate that more live roots were maintained on snags connected to living trees with a large graft and that roots located within $90^{\circ}$ of the root grafted to the live tree persisted longer. Also, tree ring index in the living trees significantly increased following manual thinning, but was unaffected when the grafted partner died naturally. Grafts with large phloem connections maintained a higher number of live roots on snags, than grafts with small connections.
\end{abstract}

root graft / snag / manual thinning / competition / lodgepole pine

Résumé - Persistance et fonctions de racines de souches de Pinus contorta présentant des anastomoses avec des arbres vivants. En Alberta (Canada), de couples d'arbres (Pinus contorta) présentant des anastomoses racinaires ont été sélectionnés pour étudier la longévité et la disposition des racines de souches connectées à des arbres vivants, et préciser l'impact des ces racines résiduelles sur la croissance en diamètre de l'arbre vivant. Dans une seconde étude, des bosquets denses d'arbres anastomosés ont été éclaircis manuellement, et les arbres conservés ont été coupés après deux saisons de végétation. Les résultat indiquent que sur ces souches connectées à des arbres vivants, de nombreuses racines ont survécu ; de plus, les racines présentes dans un secteur de $90^{\circ}$ par rapport à une anastomose avec l'arbre vivant, persistent nettement plus longtemps sur ces souches que les autres. De plus, la croissance des cernes d'arbres vivants augmentait fortement suite à l'éclaircie, mais pas suite à une mort naturelle de l'arbre partenaire anastomosé. Les anastomoses avec de fortes connections au niveau du liber ont permis de maintenir en vie un plus grand nombre de racines sur les souches que celles avec de faibles zones de contact.

greffe de racine / chicot / éclaircie manuelle / compétition / Pinus contorta

\section{INTRODUCTION}

Living roots on dead trees (snags) and stumps connected to living trees with a root graft are a common occurrence in many coniferous forest stands (e.g., $[3,7,9,12,18])$. Following the death of individual trees (either from natural causes or cutting), the base of the stem and the root systems of the remaining snags and stumps can be kept alive through the transfer of carbohydrates via root grafts from living neighbouring trees (e.g., $[4,16])$. Stumps not grafted to living trees can persist for up to one growing season after removal of the photosynthesizing tops [3], but survival beyond one year has always been attributed to photosynthate transferred across root grafts from living trees (e.g., $[3,7,12,16,18])$.

There have been several studies that have assessed the survival rates of above-ground portions of snags and stumps following removal of the crown (e.g., $[3,7,12,15,16])$. However, there have been no replicated studies that investigated the longevity or mortality patterns of the root systems of stumps or snags grafted to living trees. While there have been studies of transfer of resource through root graft of living trees

\footnotetext{
* Corresponding author: victor.lieffers@ualberta.ca
}

[10] it is currently unclear whether the transfer of resources to living stumps or snags affects the diameter growth of living grafted partners. There have been reports of significantly increased growth [4], decreased growth [7] and no change in growth [19] in living trees grafted to living stumps relative to non-grafted control trees. Also, previous studies have not differentiated between the effects of a grafted partner dying gradually from natural causes (e.g., competition) or suddenly following manual cutting. When a tree is suppressed by its neighbours, death may take several years and the suppressed tree may slowly drain resources from its grafted partner [10]. Conversely, relatively healthy grafted partners may be killed suddenly via manual thinning; under these circumstances, above-ground parts would not be a potential sink for resources but a large grafted root system could become a sudden drain of resources. This may be a cause for the slow release following thinning which has been reported in some studies $[8,11]$.

Lodgepole pine (Pinus contorta var. latifolia Dougl. ex Loud.) was selected for this study because it has been previously shown to readily form root grafts, especially after 15 years of age [9]. Also, lodgepole pine is a shade 
intolerant species that has a tendency to form extremely dense single-species stands following natural disturbances [13]. Therefore, many lodgepole pine stands are manually thinned during the juvenile stages [13]. As a result, it is likely that dense lodgepole pine stands undergoing self-thinning are composed of living trees grafted to at least one snag or stump with live roots.

The objectives of this study were to determine the longevity and location of live roots on lodgepole pine snags and stumps grafted to living trees and to determine whether these live roots affect the diameter growth of living trees.

\section{MATERIALS AND METHODS}

\subsection{Natural mortality study}

This study used plots established within a large, pure fire-origin lodgepole pine forest near Hinton, Alberta (53 $23^{\circ} 60^{\prime \prime} \mathrm{N} ; 117^{\circ} 34^{\prime}$ 60 " W). Live trees in the study area averaged $8.1 \mathrm{~cm}$ in stem diameter (range: $5.7-11.8 \mathrm{~cm}$, measured at $10 \mathrm{~cm}$ height) and 45.1 years of age (range: 39-54 years, measured at $10 \mathrm{~cm}$ height). Dead standing trees (snags) in the study area averaged $4.9 \mathrm{~cm}$ in stem diameter (range: $2.8-7.0 \mathrm{~cm}$, measured at $10 \mathrm{~cm}$ height), 31.9 years of age (range: 22-39 years, measured at $10 \mathrm{~cm}$ height) and had been dead for an average of 14.7 years (range: $8-23$ years, measured at $10 \mathrm{~cm}$ height) (see below). As there was no evidence of root rots, stem decay or reports of defoliating insects, we assumed that trees died of natural suppression. Trees were taken from flat or slightly inclined terrain and soils were Brunisolic Grey Luvisols.

Twenty pairs of trees were located in August 2004. Each pair contained one living tree and one snag (completely dead above ground) connected with a root graft. Trees were within $30 \mathrm{~cm}$ of each other and were presumed to be grafted together prior to the death of the snag. The grafted pair was at least $80 \mathrm{~cm}$ from other trees; trees spaced $>80 \mathrm{~cm}$ apart had low probability of being grafted [9]. All pairs were located at least $20 \mathrm{~m}$ apart. The root system of each tree pair was manually excavated with spade and pulaski to a depth of $30 \mathrm{~cm}$ and the grafting status was verified. The grafted stumps and large roots were removed intact from the ground and transported to the laboratory for analysis.

Stem diameter and tree age were measured on all trees on a stem section taken at $10 \mathrm{~cm}$ height. Tree ring widths were measured on the stem sections with a Parker Instruments ${ }^{\circledR}$ stage micrometer (Vickers Instruments York, England) and dissecting microscope. Starting with the outermost ring, each ring was counted and the relative width of each tree ring was noted. A master chronology of the relative size of annual rings for each calendar year was determined from the living trees. Calendar years were then assigned to rings in the snags by comparing the patterns of relative ring size in living trees with their dead grafted partners $[17,20]$. From this analysis, the year of death (defined as the date of the last annual ring) was established for all snags. This assumes that there were no missing rings in years with very slow growth prior to death. Also, all grafted roots were removed from the grafted root system, glued to a board and then serial sectioned with a band saw into $0.25-0.50 \mathrm{~cm}$ thick sections. The sections were either sanded or carefully shaved with a razor blade prior to examination of the annual rings. Graft sections were examined and the age of the graft, the area of the xylem across the graft and the circumference of the phloem across the graft were measured and recorded. Most of the xylem area of these roots was sapwood. The grafted circumference of the phloem was assumed to be the length of the bark/phloem contact between the two roots, around the graft.

Tree ring index (TRI) of the stem was also determined for each live tree. To calculate TRI, annual ring widths were plotted for each calendar year. The highest growth peak at least ten years prior to the death of the snag was identified. An exponential function was then fitted to data for each tree starting at this growth peak and ending the year that the snag died. This exponential function was used to extrapolate the expected ring widths after the death of the snag. Tree ring index was calculated by dividing the observed ring widths by the expected ring widths for the two years immediately following the death of the snag [6]. Also, in order to determine the survivorship of roots relative to the position of the graft, the radial positions of all live and dead coarse roots ( $>1 \mathrm{~cm}$ diameter), on each snag were recorded relative to the position of the graft. Roots were categorized as $<90^{\circ}$ or $>90^{\circ}$ from the grafted root.

\subsection{Manual thinning study}

All trees were selected from areas at least $50 \mathrm{~m}$ apart within three general areas containing pure fire-origin lodgepole pine, near Swan Hills, Alberta $\left(54^{\circ} 45^{\prime} 12^{\prime \prime} \mathrm{N} ; 115^{\circ} 42^{\prime} 14^{\prime}\right.$ W). Trees in the study area averaged $5.7 \mathrm{~cm}$ in stem diameter (range: $2.2-12.5 \mathrm{~cm}$, measured at $10 \mathrm{~cm}$ height) and 19.9 years of age (range: $16-30$ years, measured at $10 \mathrm{~cm}$ height). Sites had less than $10 \%$ slope and the soils were Grey Luvisols.

Eight plots (ranging in size from 1-4 $\mathrm{m}^{2}$ ), each containing 3-6 trees, were established in May 2003. Plots were located in areas with local clumps of trees with high stem densities $\left(>25000 \mathrm{stem} \mathrm{ha}^{-1}\right.$ ) because these areas have been shown to have a high probability of root grafting [9]. Clumps were separated from adjacent trees by at least $1 \mathrm{~m}$. At each plot, a dominant or co-dominant leave tree in the centre of the clump was selected and the surrounding trees were cut with a brush saw. Trees selected as leave trees were healthy and had good form. Plots were located at least $20 \mathrm{~m}$ apart. Also, eleven dominant/co-dominant non-grafted control trees were selected from the area surrounding the study plots; these trees were locally isolated from other trees by $>80 \mathrm{~cm}$ but not more than $150 \mathrm{~cm}$. Trees of this size and proximity have a very low probability of being grafted to another individual [9] and this was verified by excavation. Stems were cut and the stem sections were transported to the laboratory. Although the local densities around the treated trees (clumps) and control trees (single stem) were not similar in this study, the densities at a somewhat larger scale (e.g. $2+$ m radius) surrounding the focal tree or clump were similar.

In August 2004, two growing seasons after the thinning treatment, all plot areas were excavated to a depth of approximately 30 $40 \mathrm{~cm}$ so that all lateral roots were exposed. Following excavation, the grafted/non-grafted status of all plot trees was determined. The stumps and large roots of all trees grafted to the leave tree were removed intact from the ground and transported to the laboratory for analysis. Any stumps not grafted to the leave tree were eliminated from the study.

Stem diameter, tree age and tree ring widths were measured and recorded on the leave trees, control trees and the stumps of trees removed during the manual thinning treatment. The position of all living and dead coarse roots $(>1 \mathrm{~cm})$ on each stump was also recorded. Further, tree ring index (TRI) was calculated for the leave trees and the non-grafted control trees in the same manner as described above. 


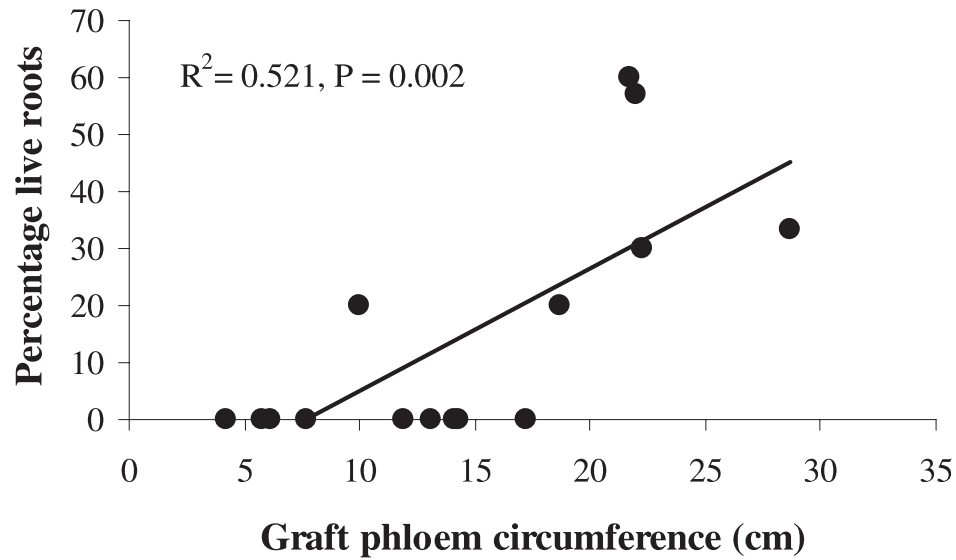

Figure 1. Relationship between the percentage of living roots on snags and the circumference of the phloem connection of the graft connecting the snag to a living tree in the natural mortality study. Note that in some cases, the phloem circumference reported was the total of more than one graft connecting the two trees.
All grafts were removed from the grafted system and were serial sectioned into $0.25-0.50 \mathrm{~cm}$ thick sections so that graft age, graft xylem area and graft phloem circumference could be determined.

Carbohydrate concentrations of the roots were sampled in order to determine the rate of decline of $\mathrm{C}$ reserves in the roots of cut trees. Immediately following excavation, samples of living roots from leave trees, control trees and stumps were collected. Roots collected for carbohydrate analysis were $1-2 \mathrm{~cm}$ in diameter and were $>45^{\circ}$ from the root grafted to the living tree. All root samples (xylem and phloem tissues) were dried, ground with a Wiley mill and after soluble sugars were extracted from the tissue with hot ethanol (85\%), their concentrations were determined colorimetrically using phenolsulfuric acid. Starch in the tissues was hydrolysed using an enzyme mixture of $\alpha$ amylase and amyloglucosidase and then measured colorimetrically using glucose oxidase/peroxidase-o-dianisidine solution [5].

\subsection{Statistical analysis}

The relationship between the percentage of live roots on the snag or stump and the circumference of the phloem across the graft was analyzed with linear regression. Linear regression was also used to evaluate the relationship between the percentage of live roots on the snag and the time since snag death in the natural mortality study. Because all stumps had been dead for two years in the manual thinning study, this relationship was not tested in this study. Also, the relationships between tree ring index (TRI) and stem diameter of the snag or stump, age of the snag or stump, area of the xylem across the graft, circumference of the phloem across the graft, age of the graft and the percentage of live roots on the snag or stump were analyzed with multiple linear regression. The relationships between the age of the graft and graft xylem area and graft phloem circumference were analyzed with linear regression. If a tree pair was connected by more than one graft, the xylem area or phloem circumference of all grafts was summed so that the total xylem area or phloem circumference connecting two trees was analyzed.

The data describing the positions of the living roots on the snags or stumps was analyzed with chi-square analysis. The root sugar and starch concentrations in leave trees, stumps and control trees were analyzed with a completely randomized one-way ANOVA and the changes in TRI before and after the death of a grafted partner were analyzed with paired $t$-tests.

All data in both the natural mortality and manual thinning studies conformed to the assumptions of normality and equality of variance.
Release 8.1 of SAS $^{\circledR}$ (SAS Institute Inc. Cary, NC) was used for all analyses, multiple comparisons were done with lsd tests and a significance level of $\alpha=0.05$ was used for all response variables.

\section{RESULTS}

In the natural mortality study, the percentage of live roots on snags grafted to living trees was correlated with the circumference of the phloem connection across the graft $(P=0.002$, $R^{2}=0.521$ ). In this study, virtually all snags with live roots were connected to a living tree with a graft phloem circumference of at least $20 \mathrm{~cm}$ (Fig. 1). If roots were alive on the distal side of the stump there was living phloem on at least part of the stump of the snag. We did not, however, observe a significant relationship between the percentage of live roots and graft phloem circumference in the manual thinning study $(P=0.471)$. Two years after manual thinning, approximately $33 \%$ of roots originating from the stump were alive regardless of the size of the graft phloem circumference. There was also no significant relationship between the percentage of live roots on the snag and the time that the snag had been dead in the natural mortality study $(P=0.222)$. Nevertheless, we did not observe any live roots on snags that had been dead for longer than 15 years.

In the natural mortality study, the positions of live roots on the snag were significantly affected by proximity to the graft with the living tree $(P=0.005)$. In this study, $83 \%$ of live roots on the snag were located within $90^{\circ}$ of the root graft with the living tree (Fig. 2). However, in the manual thinning study there were no significant differences in number of living roots on the near vs. far side of the stump two years after manual thinning ( $P=0.140$, Fig. 2$)$.

Tree ring index (TRI) of the leave trees in the manual thinning study significantly increased following removal of the surrounding grafted partners $(P=0.002$, Fig. 3). Prior to thinning, leave tree TRI averaged 1.00 and this value increased to 1.35 in the two years following thinning. Over the same two time periods, the TRI of control trees was not significantly different from the TRI of leave trees in the two years prior to thinning $(P=0.212$, Fig. 3$)$, but was significantly lower than the thinned plots in the two years immediately following thinning 


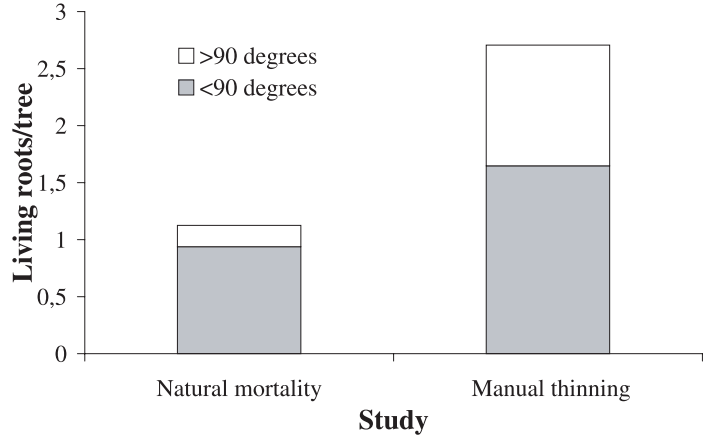

Figure 2. Number of living roots per tree on snags and stumps in the natural mortality and manual thinning studies. Living roots on the stumps or snags were placed into two categories; those located $<90^{\circ}$ from the point of attachment of the grafted root and those $>90^{\circ}$ from the point of attachment.

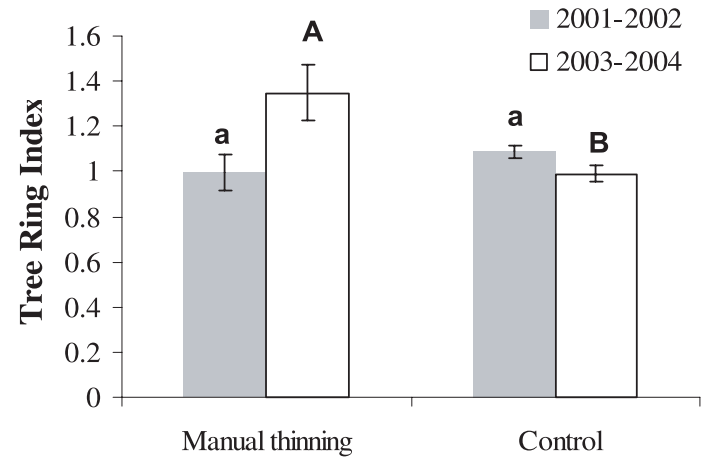

Type of tree

Figure 3. Tree ring index during 2001-2002 (before thinning) and 2003-2004 (after thinning) in live trees that had their grafted partners removed (manual thinning) and in trees that received no treatment (control). Bars represent the standard error of the mean. Bars with different letters are significantly different at the $95 \%$ confidence level. Data for 2001-2002 and 2003-2004 were analyzed separately.

$(P=0.005$, Fig. 3$)$. In the natural mortality study, TRI in the living trees was not significantly affected by the death of their grafted partner $(P=0.205)$, increasing from 1.00 to 1.04 after the death of the partner.

Following the death of roots directly grafted to the roots of living trees, the living root appeared to distinctly wall-off the xylem connecting it to the dead root (Fig. 4). In some circumstances, there was some staining of living roots through the grafted area, but there was no evidence of decay. There was also no evidence of any callus tissue formation on the exposed stump or snag surfaces in either the natural mortality or manual thinning studies. However, all stumps with live roots in the manual thinning study had formed a resin cap on the exposed stump surface two years after thinning.

No significant differences were detected in the slope or intercepts between the xylem area of grafts and graft age or the phloem circumference of grafts and graft age in the natural mortality and manual thinning studies $(P>0.478)$, so the

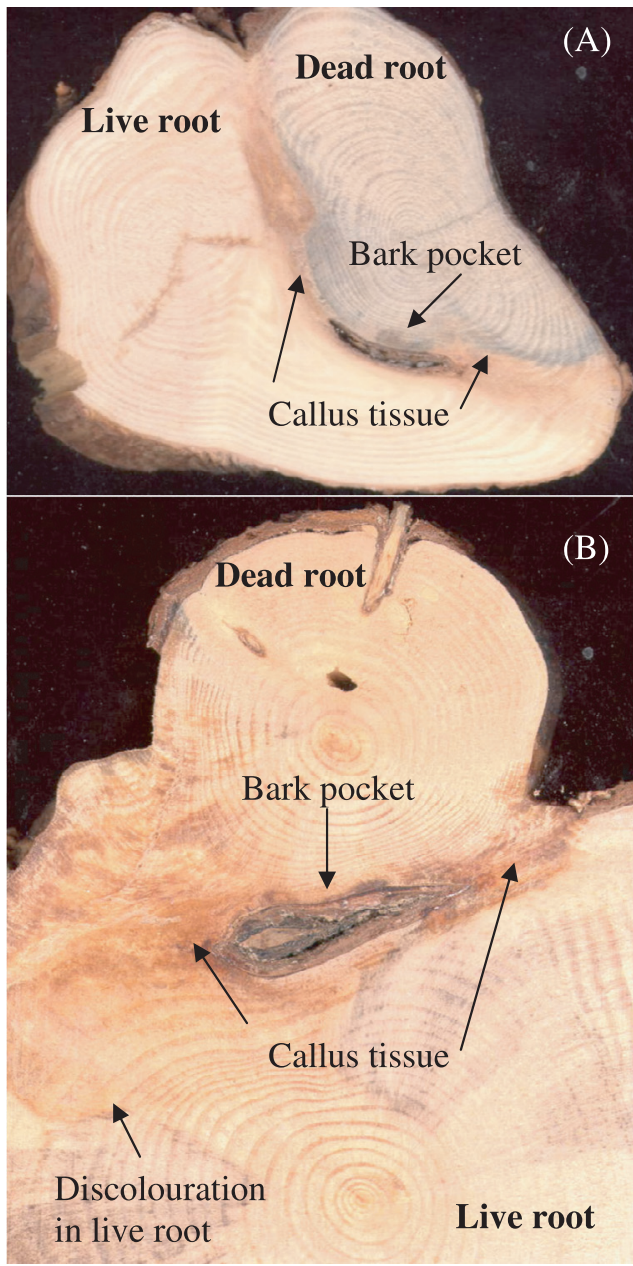

Figure 4. Photographs of root grafts between live and dead roots where there was no discolouration in the live root following the death of the dead root (A) and where there was some discolouration in the live root following the death of the dead root (B). The bark pocket and callus tissue denote the point of graft formation.

two studies were combined for this analysis. Both graft xylem area $\left(P<0.001, R^{2}=0.189\right)$ and graft phloem circumference $\left(P<0.001, R^{2}=0.210\right)$ increased with increasing graft age (Figs. 5A and 5B). However, no significant relationships were detected between TRI and diameter of the snag or stump, age of the snag or stump, graft xylem area, graft phloem circumference, age of the graft or the percentage of live roots on the snag or stump $(P>0.100)$ in either the natural mortality or manual thinning studies.

In the manual thinning study, starch concentrations in the roots of leave trees and control trees were significantly higher than in living roots on stumps $(P=0.016)$. On average, starch concentrations were 2.7 times higher in roots from leave trees and control trees relative to those from stumps $(2.7 \%$ vs. $1.0 \%$, Fig. 6). However, sugar concentrations in the live roots of leave trees and control trees were not significantly different from the sugar concentrations in stump roots $(P=0.286)$; two years following thinning, sugar concentrations averaged $3.7 \%$ (Fig. 6). 


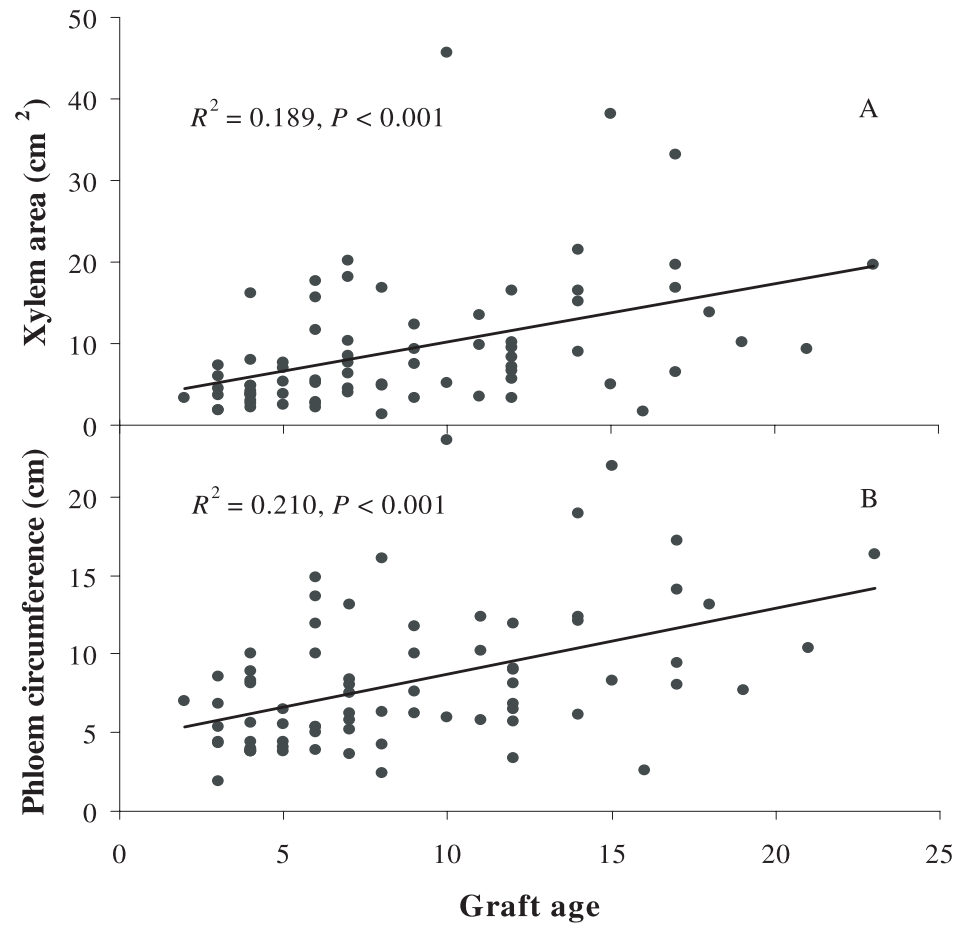

Figure 5. Relationship between graft age (years since grafting) and graft xylem area (A) and phloem circumference across the graft (B). These relationships include data from both the natural mortality and manual thinning studies.

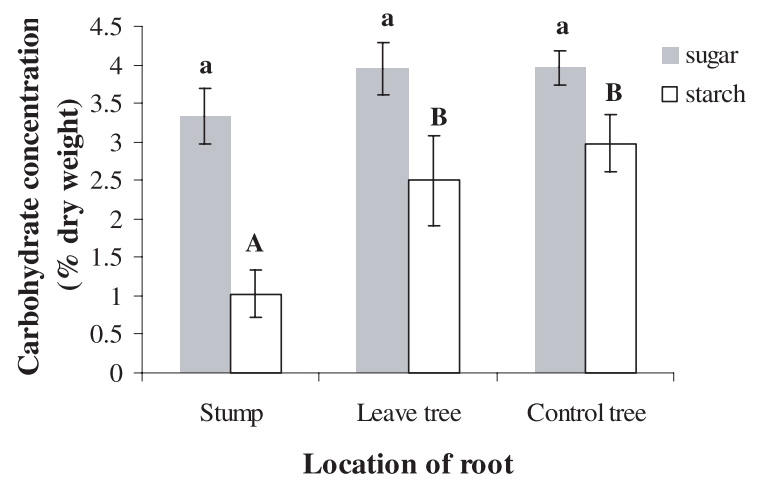

Figure 6. Sugar and starch concentrations in living roots of stumps, leave trees and control trees in August 2004. The stumps were from trees cut two growing seasons previously during a manual thinning treatment, the leave trees were grafted to the stumps and the control trees were non-grafted and undisturbed. Bars represent the standard error of the mean. Bars with different letters are significantly different at the $95 \%$ confidence level. Data for sugar and starch were analyzed separately.

\section{DISCUSSION}

Our study demonstrates that the number of live roots sustained on snags grafted to living trees was related to the size of the phloem connection across the graft. In fact, virtually all snags with live roots were grafted to a living tree with a phloem circumference of at least $20 \mathrm{~cm}$ across the graft (Fig. 1). Logically, grafts with larger phloem pathways should be able to transport greater quantities of carbohydrates to the snag or stump root system, which should allow for greater root longevity. Indeed, previous research has indicated that greater quantities of starch were transferred from non-shaded trees to their deeply shaded partners via root grafts when the phloem circumference of the graft was large [10].

In the natural mortality study, we did not detect a significant relationship between the proportion of live roots on snags grafted to living trees and the length of time that the snag had been dead. However, given the fact that there were relatively few roots on the distal side of the snag, there had to have been significant mortality of roots on this side relatively soon after mortality. Further, most of the phloem in the stump of snags seemed to die relatively soon after death of the above-ground portion. Previous studies of the longevity of above-ground portions of stumps following partial cutting or other disturbances have reported that species that form callus tissue over the exposed stump surface soon after death survive longer. The callus tissue produced by Douglas fir (Pseudotsuga menziesii (Mirb.) Franco) and true firs (Abies spp.) appear to allow better protection from fungal and insect attacks than the simple resin cap produced on exposed stumps of eastern white pine (Pinus strobus L.), ponderosa pine (Pinus ponderosa Dougl. ex Laws.) $[3,12,14,15]$ and lodgepole pine (this study). We did not observe any callus tissue formation in either our natural mortality or manual thinning studies and based on previous work, callus tissue formation appears to be rare in most pine species $[3,12,15,16]$. Considering that the stump is the critical junction point for the graft to access more distal roots, decomposition of the stump by saprophytic fungi would break the transport of carbohydrates and/or water through the stump and the growing tips of more distal roots would be cut off from the living tree This theory of how roots die is further strengthened by the fact that there was little evidence of pathogens 
invading the graft of these trees prior to the final death of the snag or stump root (Fig. 4, P. Blenis, pers. observ.), suggesting that the final cause of death was more distal than the graft itself. The partial discolouration of the xylem in some grafts is likely saprophytic fungi as the discoloured tissue in the live roots was always solid. Interestingly, even after several years of graft connection, the boundary between live and dead tissue appeared to be defined by the lines of the original roots (Fig. 4).

In our manual thinning study, the live roots were fairly evenly distributed around the stumps two years after thinning (Fig. 2). However, in our study of natural mortality, $83 \%$ of live snag roots were located within $90^{\circ}$ of the junction of the grafted root to the tree base and only $17 \%$ were on the far side of the tree base (Fig. 2). These results correspond with those of Bormann [3] who reported that the majority of living tissue visible on eastern white pine stumps was located on the side of the stump closest to the living grafted partner. It has been shown that there is very little lateral movement of solutes in xylem tissues of stumps grafted to living trees $[3,4]$. Further, it has been suggested that in many cases, root grafts between lodgepole pine trees may be too small to transfer significant amounts of carbohydrates between trees [10]. Therefore, it is unlikely that the root or stump tissue distal to the graft would receive adequate carbohydrates from the living tree for longterm survival.

In the manual thinning study, the inheritance of a large grafted root system did not appear to have a negative impact on the growth of the residual tree. The fact that tree ring index of leave trees grafted to cut trees significantly increased following manual thinning (Fig. 3) could be related to either the benefits of capturing more roots, or to the increased light and soil resource availability following thinning (e.g., $[1,2,21]$ ) or a combination of both. However, when mortality occurred naturally and the dead trees remained as snags, there was little apparent benefit to the residual tree. In this case, the death of a single intermediate tree via natural causes would only provide a small increase in the availability of resources to the remaining trees. Nevertheless, if the grafted roots of the dying tree were beneficial to the residual tree, we would expect to see a positive growth response in the residual tree as water and nutrient availability should increase. However, tracer movement in the xylem tissues of stumps grafted to living trees has been considered slow and inefficient [4], which suggests that water uptake by these roots may be minimal. Conversely, movement of carbohydrates from the living tree to support a relatively large root system on the dead tree could easily overwhelm any positive effects coming from increased water uptake associated with these roots.

This study shows that in lodgepole pine, if two trees are grafted together and one tree dies, roots on the dead tree may remain alive for up to 15 years. Roots on the dead tree are more likely to remain alive on the on the side of the stump with the root connected to the living tree and if the graft had a large length of connecting phloem. When trees died naturally, there was no apparent benefit to growth of the surviving tree by the capture of part of the root system of the dead tree. When the companion tree was cut, the leave tree tended to grow faster but is not clear if this is because of capture of the root system or relaxation of intraspecific competition.

Acknowledgements: The authors would like to thank Ian Kwantes, James Reid, Mike Klaczek, Jennifer Hofman and Pak Chow for field and laboratory assistance. Funding was provided by West Fraser Mills, Weyerhaeuser Company, the Killam Trust, the University of Alberta and the Natural Sciences and Engineering Research Council of Canada (NSERC).

\section{REFERENCES}

[1] Alexander R.R., Thinning lodgepole pine in the central Rocky Mountains, J. For. 58 (1960) 99-104.

[2] Bella I.E., De Franceschi J.P., Growth of lodgepole pine after mechanical strip thinning in Alberta: 15-year results, For. Chron. 58 (1982) 131-135.

[3] Bormann F.H., Intraspecific root grafting and the survival of eastern white pine stumps, For. Sci. 7 (1961) 247-256.

[4] Bormann F.H., The structure, function, and ecological significance of root grafts in Pinus strobus L., Ecol. Monogr. 36 (1966) 1-26.

[5] Chow P.S., Landhäusser S.M., A method for routine measurements of total sugar and starch content in woody plant tissues, Tree Physiol. 24 (2004) 1129-1136.

[6] Dang Q.L., Lieffers V.J., Assessment of patterns of response of tree ring growth of black spruce following peatland drainage, Can. J. For. Res. 19 (1989) 924-929.

[7] Eis S., Root grafts and their silvicultural implications, Can. J. For. Res. 2 (1972) 111-120.

[8] Farnden C., Herring L., Severely repressed lodgepole pine responds to thinning and fertilization: 19-year results, For. Chron. 78 (2002) 404-414.

[9] Fraser E.C., Lieffers V.J., Landhäusser S.M., Age, stand density and tree size as factors in root and basal grafting of lodgepole pine, Can. J. Bot. 83 (2005) 983-988.

[10] Fraser E.C., Lieffers V.J., Landhäusser S.M., Carbohydrate transfer through root grafts to support shaded trees, Tree Physiol. 26 (2006) 1019-1023.

[11] Johnstone W.D., Juvenile spacing of 25-year old lodgepole pine in western Alberta, Canadian Forest Service, Edmonton, AB, Information Report NOR-X-244, 1982.

[12] Lanner R.M., Living stumps in the Sierra Nevada, Ecol. 42 (1961) $170-173$.

[13] Lotan J.E., Critchfield W.B., Lodgepole pine, in: Burns R.M., Honkala B.H. (Eds.), Silvics of North America Volume 1: Conifers, USA Department of Agriculture, Washington D.C., 1990, pp. 302315.

[14] Miller L., Woods F.W., Root grafting in loblolly pine, Bot. Gaz. 126(1965) 252-255.

[15] Newins H.S., The natural root grafting of conifers, Proc. Soc. Am. For. 11 (1916) 394-404.

[16] Schultz R.P., Woods F.W., The frequency and implications of intraspecific root grafting in loblolly pine, For. Sci. 13(1967) 226239.

[17] Stokes M.A., Smiley T.L., An introduction to tree ring dating, Univ. Chicago Press, Chicago, Illinois, 1968.

[18] Stone E.L., The communal root system of red pine: growth of girdled trees, For. Sci. 20 (1974) 294-305.

[19] Walters M.D., Effect of natural root grafting on diameter growth of Douglas fir (Pseudotsuga menziesii), M.F. thesis, Univ. Washington, Seattle, Washington, 1963.

[20] Yamaguchi D.K., A simple method for cross-dating increment cores from living trees, Can. J. For. Res. 21 (1991) 414-416.

[21] Yang R.C., Foliage and stand growth responses of semimature lodgepole pine to thinning and fertilization, Can. J. For. Res. 28 (1998) 1794-1804. 